\title{
イルメナイト砂鉱床形成の背景をなす造構運動について
}

\author{
一宮城県蒲沢鉱山周辺の地質鉱床一
}

\section{On the Regional Tectonic Movement having Influence upon the Deposition of the Kabasawa Ilmenite Placer Deposits}

\author{
斎 藤 洋 彦 (Hirohiko Saitoh)*
}

The Kabasawa placer deposit is categorized as one of the Pliocene ilmenite placer deposit and its sedimentary and conservative environment is controlled by warping movement of the Okubushi line.

The purpose of this paper lies in the research of such elements which influenced the deposition of the Kabasawa placer deposit characteristics relating to type of movement, behavior and development stage of the Okubushi line made during the Pliocene era.

The Okubushi line consists of combinations of cross structure of NW and NE branches meeting at tangent angles to each other which reflects the tectonics in the basement of this area. Of these, the NW brach plays a main role in the tectonic movement.

The NW branch of Okubushi line controlled the deposition in Pliocene Sendai Group as well as Pliocene sedimentary basin after making warping movement and bringing about an upheaval on its southwestern side and tilting subsidence on its northeastern side.

In other words, the NW branch brought about a differential movement of upheaval and subsidence through the depositional stage of Kameoka and Tatsunokuchi formation and the central part of the past upheaval changed into a depressional tilting subsidence at the depositional stage of Kitayama formation. Finally, the NW branch terminated its geologic movement with the eruption of tuff (acidic volcanic deposits) at the depositional stage of Hirosegawa tuff.

The Kabasawa sandstone and conglomerate member intercalating Kabasawa ilmenite placer deposit, is a deltaic deposit which was piled up upon the region of depressional tilting subsidence during the depositional stage of Kitayama formation. It forms a circle of $2 \mathrm{~km}$ diameter and has an extraordinary thick stratum.

It is generally believed that the movement in the NW branch of Okubushi line is the result of a tectonic movement, referred to as "Green Tuff Crustal Movement", in full activity during the Miocene era and succeeded to the Pliocene era in the northeastern part of Japan.

\section{I. まえがき}

蒲沢鈗山は，宮城罢宮城郡宮城村にあり，仙台市西 北方 $12 \mathrm{~km}$ に位㽞する。本釷山の 鉱床は，鮮新統化石 イルメナイト砂鉙床に属し，学界扰よび鉱山業界におい て、次の観点からひとしく注目されてきた。すなわち， 鉉休を形成するイルメナイト砂の起源は，どこにあるの か、あるいはなな゙イルメナイト砂が，蒲沢鉣山付近に
しか、滥していないのかなどの関心からである。

筆者（斎藤 1965）は，さきに青森県七戸地方に打け る，天間林鉱山の鮮新統底田砂鉄鈆床を研究した結果， 本鉣床が，後背地の挸曲連動に規定されて堆 積してい ることを報告した。その後，国内に拈ける各地の先第四 紀化石砂鉄鉱床を吟味検討した結果，この種の鍣床は， いずれも何等かの点で造構運動と密接な関連性があるこ 


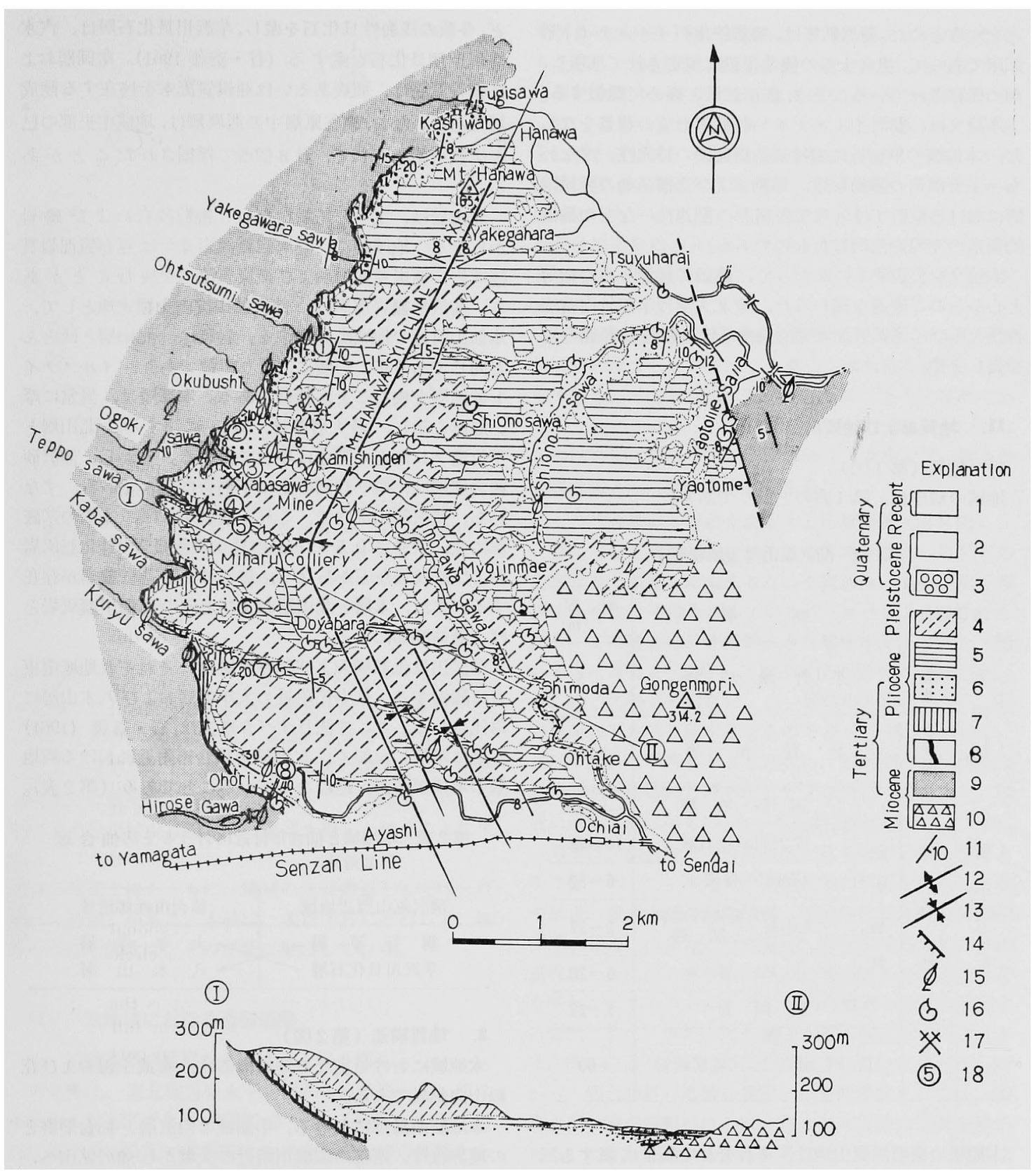

符 1 図 蒲次鉱山周辺地質図

1. Alluvial deposits 2. Terrace deposits 3. Kamishinden formation 4. Doyabara formation 5 . Imozawagawa shell bed 6. Kitayama form., Kabasawa member and Hirosegawa tuff 7. Tatsunokuchi formation 8. Kameoka formation 9. Shirasawa formation 10. Mitaki basalt 11. Dip and strike 12. Anticlinal axis 13. Synclinal axis 14. Fault 15. Plant fossil 16. Shell fossil 17. Kabasawa mine 18. Outcrop of ilmenite sand 
とをつきとめた。蒲沢鉣床は，鮮新統化石イルメナイト砂 鉣床であって，奥武士線の捹曲運動に挸定されて堆程し， かつ保存されていることは，底田鉱床と敝めて類似する。

本諭文は，溥沢イルメナイト矽鉣林形成の背量をなし た，本地域の焦新世に和ける造棈運動の特異性，すなわ ら一主要楧造の運動形態，举動および造構運動の発展段 階における位置ずけと堆積作用との䦥连性一などの造構 的要素の㠰明を意図したものである。

本諭文を公表するにあたって，終始ご想篤なるで指導 と心からのご鞭達を賜かった，東北大学理学部竹内常彦 教授ならびに選鉝製鍊研究所長南部松夫教授に深謝の意 を表します。

\section{II，地啠および地留構造}

1. 地質（第 1図）

地域の層序は、第1表のとおりである。

第 1 表 蒲沢鍍山周辺地域層序

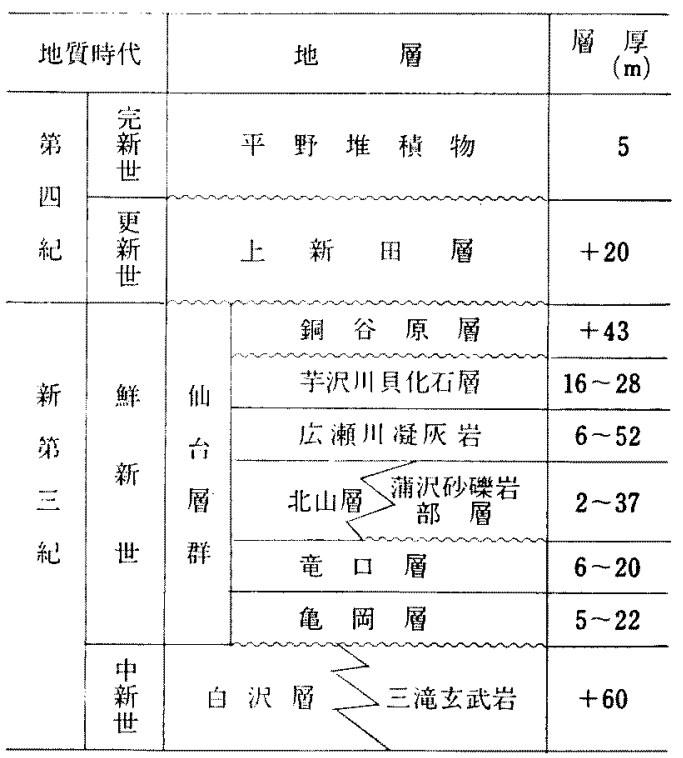

本地域の東西両側山地は，それぞれ中新世に属する三 滝玄武岩わよび白沢層により構成されれる。仙台層群は， これら両山地の間を占め，地域の中央部に分布する。

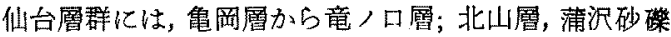
岩部層就上び広瀬川凝灭岩から芋沢川貝化石層の如く，

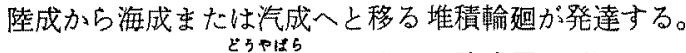
たたし、最上部の銅谷原周だけは，陸成層で終ってい る。これら各地層の特徵は，次のとおりである。

童ノ口層は, Fortipecten Takahashii (Yokoyama) な
と，多数の浅海性貝化石を産し，芋沢川貝化石層は，汽水

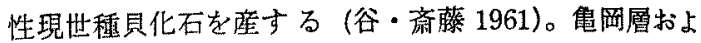

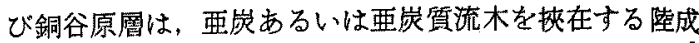

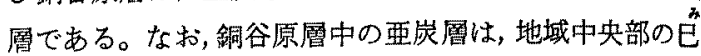
春岩鉣を始めとして，計 8 個所で採掘されたことがあ 名。

北山尿は，主として粗粒ないし細粒砂岩および磪岩 からなる。地域的に，凝灰岩質泥岩または豆石質泥岩質 凝灭岩，亜炭質泥岩および亜岸質流木を摤むことがあ る。渻沢砂碟岩部層は, 蒲沢鉣山坑内を標式地として, 本鉣山附近の地域に発達する。岩質は，北山層とほとん と同じであるが、一般に，より粗粒であり、イルメナイ 卜砂鉣層を挾さことが特徴である。本部層は，異常に厚

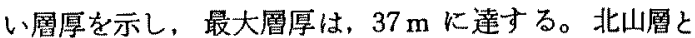
下位竜ノ口層との関係は整合で接する。しかし，蒲沢砂

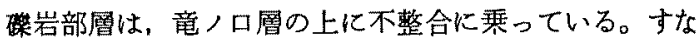
わら、茷沢鉱山坑内で，これを観察すれば，本層の基底 部には，大きさ $0.5 \sim 3 \mathrm{~cm}$ の珪化黑色頁岩・珪化凝灰岩 扎よび流紋岩などからなる，稯角のある基底碟岩が存在 する。また，本層と北山層および上位の広瀬川凝灰岩と は，激移関係にある。

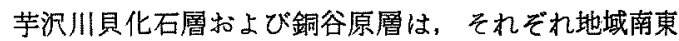
万に绦接する。仙台市附近の大年寺層および八木山層に 対比される。ここで注目すべき事実は，谷・斎藤 (1961) が既に指摘した如く，本地域と仙台市附近に㧍ける両地 層の堆積順序が，这になっていることである(第 2 表)。

第 2 表 本地域と仙台市付近における上部仙台層 群の対比

\begin{tabular}{|c|c|}
\hline 渄沢釷山周辺地域 & 仙台市近郊地域 \\
\hline $\begin{array}{l}\text { 銅 谷 原 層 } \\
\text { 芋沢川貝化石層 }\end{array}$ & $\begin{array}{llll}\text { 一大 } & \text { 年 } & \text { 層 } \\
\text { 八 } & \text { 木 } 山 & \text { 層 }\end{array}$ \\
\hline
\end{tabular}

\section{2. 地質楧造（第 2 図）}

本地域における主なる地質構造は，奥武士線および花 輸山向斜軸である。

本地域西縁部における，中新統の白沢層と仙台層群と の境界線は，南部の広瀬川附近の大堀から蒲沢鉱山人， NW 方向に延び，ここで一旦直角に曲折し，奥武士を 経てNE方向に延び，藤沢にいたっている。本線沿いの 仙台㬝群は，地域の一般傾斜 $5^{\circ} \sim 10^{\circ}$ よりる急傾斜を示 している。すなわら走向傾斜を整理してみると，大堀〜蒲 沢鉣山の間は, 走向 NW 万向を示し, 東 $15^{\circ} \sim 40^{\circ}$ 傾斜, 㳦沢鉱山〜奥武士〜藤沢間は，走向 $\mathrm{NE}$ 方向, 東 $10^{\circ} \sim$ $20^{\circ}$ 傾斜亡，前者よりる綬傾斜を示している。このよ5 に，鮮新統の仙台層群と下位の中新統白沢層の間におい 


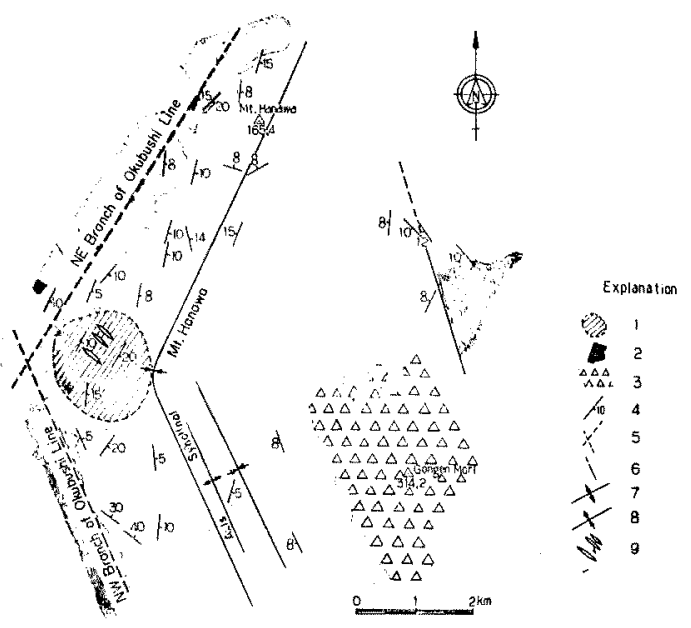

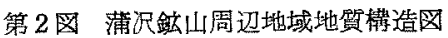

1. Kabasawa sandstone and conglomerate member 2. Shirasawa formation 3. Mitaki basalt 4 . Dip and strike 5 . Okubushi line 6. Fault 7. Anticlinal axis 8. Synclinal axis

9. Kabasawa ilmenite placer deposit

て, 地圈の傾斜が急変している一連の棈造は，生出(1955) の定義した，いわゆる「鈎取一奥武士線」炏該当する。 しかしながら，本地域では，本線の北半分だけがよぎっ ているだけであって，鈎取を通る本線の南半分は，直接 本地域とは無関係である。したがって，本諭文では，本 線の北半分たけを，略して「奥武士線」と呼ぶことにす る。

次に奥武士線とともに，地域の主要構造としては「花 輪山向斜軸 がある。本軸は，舆武士線に平行して，地 域中心部支南北に，〈の字型に綐断している。

\section{III. 本地域における造構運動}

1. 造構運動の性格および特徽（第 2 図）

本地域は，東北地方を太平洋側から日本海八と，斜に 縦断与る構造区である陸羽区の中の「松島一本荘」带 内に位する。松島一本荘带恃，造山性隆起带の性格をむ つ地質棈造上の異常带であり，その中には NWと NE 万向の直角以交わる二構浩が発達している（生出, 大沼 1960)。これら両構造方向は，中期中新世から活動を開 始し（仙台四研ダループ1966），その運動は，鮮新世む
で引きつがれて，奥武士線および花輪山向斜蠆の活動を

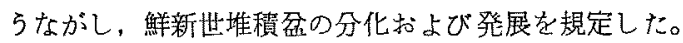

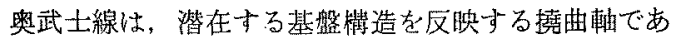
って，直角に交わる NW および NE 両軸力向**の組 合わせからなる。本線は，摫曲運陲を行なったが，その 運動形態は，差別的界降運動である。奥武士線をつくる 両楾のうち、NW 線の罟曲運動が活動の主役を演じ,

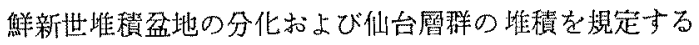
ととむに，間接的に茷沢イルメナイト砂鉣床の形成を規 定した。

花翰山向斜軸も，奥武士線之同樣に, NW と NE 两棈 造方向の組合わせからなり，潜在基盤等造を反映した構 造である。本向斜軸は，仙台曆群堆積瓧地の盆地軸であ って，Pettijohn F.J.（1962）の定義した構造軸であり， から沈降軸に相当する。また本軸は，堆積盆地の棈造軸 と沈降軸との一致する好例である。

2. 仙台層群の堆積を規定する造構運動（第 3 図）

過去の地質時代に起った地殻の舁降運動は，堆積岩の 層相分布と層厚に反映するという概念は，造棈運動を解 析する有力な手段となっている(ベロウゾフ 1954)。し かし，この概念は，比皎的大きな層序単位，すなわち階 あるいは系を2〜3 分した層序単位の解析に適用され， さらにこの場合の周厚は，広い地域の長期にわたる，升 降連動の平均的な值を示すむのである。井尻(1950， 1956)は，この考元をより厸大し，短時間か心局所的な 手降運動にも適用し得るとして「平均して沈降量は，単

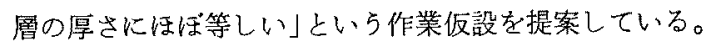

筆者は，仙台層群の堆積状態索示す曆相变化亡層厚之 を手掛りとして，本地域の造構運動の解析を試みた。そ の結果，奥武士線の運動機構，学動おさび運動の間的 変遷, 花輪山向斜軸の形成過程, 鮮新世堆積盆地の分化 過程ならびに仙台凰群の堆積と造掅運動との関連性など を明らかにすることがでさた。仙台層群の堆積を規定す る要因として，奥武士線の摫曲運動が関与していること は，既に生出（1955）により指摘されていた。しかしな がら，仙台層群の推積を規定した造構要素としては，奥 武士線の捹曲運動のほかに，花輸山向斜軸の沈降傕動が ある。これら両運動の性格は異質のものであり，前者は 仙台㬝群の堆積の前半を，後者は，その後半を規定した ものである。

鮮新世における，本地域の造棈運動の主役は，奥武土 線の摫曲運動である。しかし，奥武士 NW および NE

* 本線の定㼁については，藤田・小林・青木 (1960) らの修正意見がある。しかし、本諭文とは直接関係がないの で，生出の定義を，そのまま採用することにする。

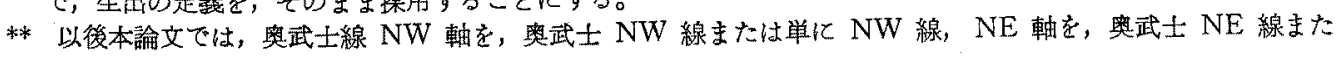
は $\mathrm{NE}$ 線と略称する。 

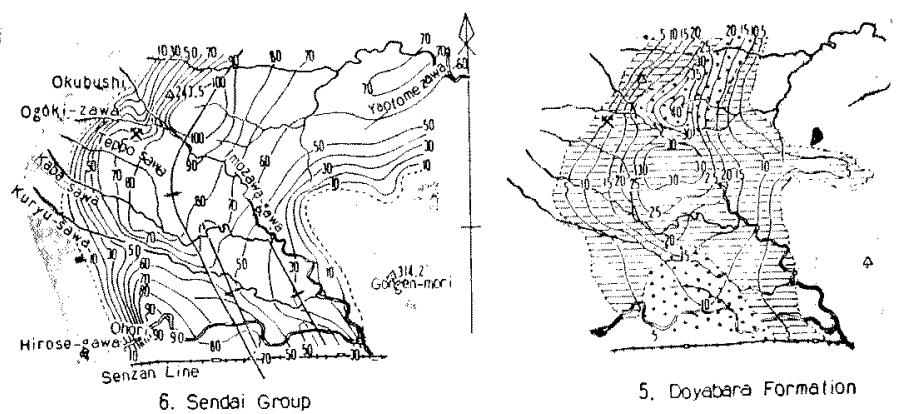

5. Doyabara Formalion

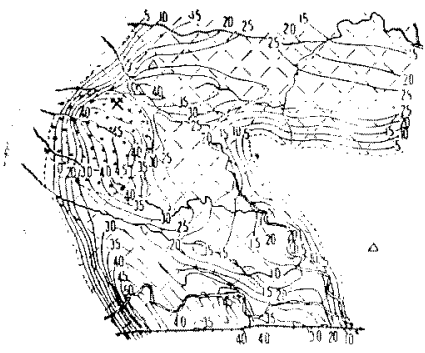

3. Kitayama Formation, Kabarawa Sandstone and Conglomerate Member \& Hiroseggwa Tuff

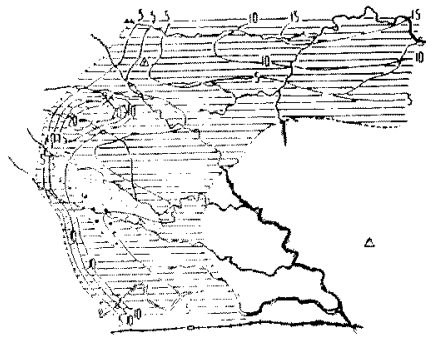

2. Talsunokuchi formation

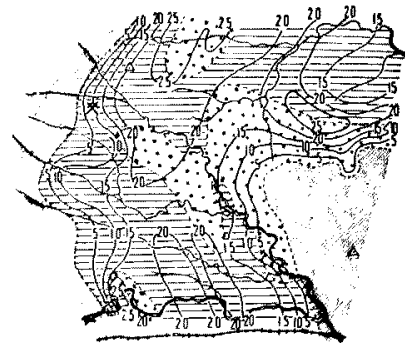

4. Imozawagawa shell bed

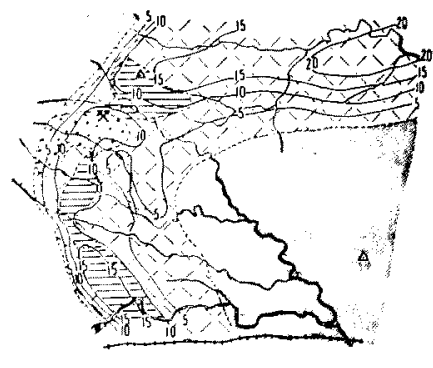

1. Kameoka Formation

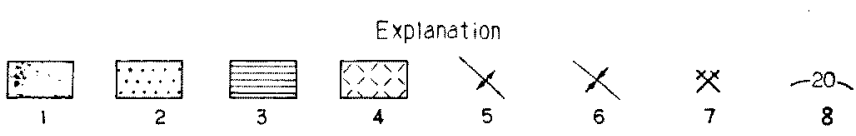

第 3 図 仙台層群等層厚線図および岩相図

1. Sirasawa formation, Mitaki basalt and others 2. Coarse sandstone and conglomerate

3. Fine sandstone, siltstone and mudstone 4. Pumice tuff and compact tuff. 5. Anticlinal axis

6. Synclinal axis 7. Ilmenite placer deposit 8. Thickness of formation (m)

両線が，同一の運動形熊をとったわけではない。これら 両線の挙動お上び運動時期は，それぞれ買なっており。 終始 NW 線が，連動の指導権をとって活発に活動し， 著しい差別的昇降運動老行なった。

龟泪尿形成期に入ると，奥武士 NW 線が活動し始力， 仙台層群堆積盈地の分化が開始され，南西端広瀬川沼い の大堀附近に，急激な沈降が起った。一方，本临成期に

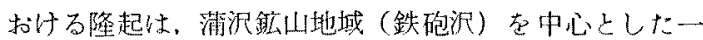
带に起った。なお，㲎岡層の層相が，その下部に砂岩又

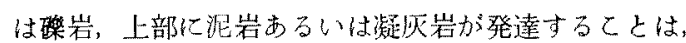
白沢層の占子る後背地か，最初は一旦急激に隆起したも のの，その後は極めて稳加な上算運動に転したたをを物 語っている。

竜ノ口層形成期に和いてい，隆起の中心が，㞮岡層形 成期の鉄砲沢加b，南部の蒲沢人と移動し，その隆起範 囲も，栗生沢とおでき沢間の一帯に拡大した。この際與 味ある事夷は，象岡層形成期に打ける隆起の中心であっ た鉄砲沢附近が，反転して比較的大きく沈降し，しか
む，この後背地が急激な隆起相を反咉した砂岩相を示す ことである。また，竜ノ口層形成期の未期には，栗生沢 から奥武士間の西緑地域だけが異常隆起を行ない，一旦 陸化していることは，䢞目に值する事実である。

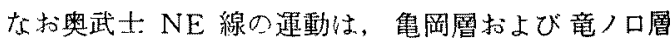
雨形成期においては，比較的稳かであった。すなわり NE 楾を境として，その南東側の水㿿は，ゆるやかに沈 降し，一力北西侧の白呮層のつくる陸域は，緩慢なる隆 起を続けていた。

北山㬝玥成期に入ると，奥武士 NW 線の暁曲運動山 急激に活発になった。すなわち，この運動は，竜ノ口層 形成期の未期に異常隆起行った鉝背後地に紋られて きて，白沢層のつく万後背地が全面的に激しい隆起に転 じ，前縁水盈が急速に，かつ大きく傾動沈降した。しの 際竜ノ口層形成期に，隆起の中心をなした蒲沢附近か， 反転して沈降の中心に転じていることは，NW 線の運 動性格の本質を示唆するものではあるまいか。また涩沢 鈗山地域は，奥武士 NW 線と NE 線との交又寸る前 
面に位し，地質楎造上の異常部にあたっている。従って北

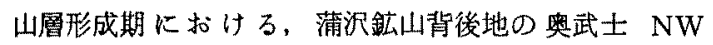
線の撓曲運動は，特殊な異常運動々考えられるので, 特 別に「蒲沢㫩曲」と呼ぶことにする。

蒲沢挜曲により，傾動沈降した前緑水跙には，湤しく 隆起する後背地汃らの侵蝕産物である砕首物が流れこ み，蒲沢砂碟岩部風が堆稓した。本部層は，三角洲堆積 物であって，直径 $2 \mathrm{~km}$ の円形をなして広がウ，また， 岩質が極めて粗いとと，異常に厚い圈厚 *をなすととか ら、沈降の激しさがらかがわれる。

本形成期においては，今まで比較的綾慢な運動を行な っていた奥武士 NE 線も，活発に活動している。しか しながら、この NE 線の運動は，飽くまで NW 線の 激しい蒲沢坽曲に引き賣られた附随的な運動であり， $\mathrm{NE}$ 線それ自体が，積極的に活動に参加したものでは ない。この事実は，NE 線に沿ら北山㬝の㬝厚㧍よび岩 相変化に反映している。すなわち，奥武士 $\mathrm{NW}$ 線上 $\mathrm{NE}$ 両線の交又寸るおごき沢附近から，NE 線に沿い， 北東方向におむむくにしたがって，漸次北山層の層厚 が少さくなる。同時に，本風の層相も粗粒砂岩質から泥 岩質へと变化している。これらの事実は，NE線沿い に，おごき沢から北東方向に㢈れるにしたがい，水盈の 傾動沈降の度合いが小さくなるとともに, 後背地の隆起 度も次第に小さくなり，NE 線の摫曲連動が，徐々にお だやかになっていったことを物語っている。

広瀬川凝灰岩形成期に入ると, 萳沢撓曲は, 寸っかり 終㹸した。NW 線の活動は, 差別的犁降運動の性質を 反吷し，傾動沈降運動は，再び旧の広瀬川地域に民って いる。本形成期における NW 線沿いの滞水盆は, 全般 的にゆっくりと傾動沈降していき，後背地の白沢層が占 める地域も，緩慢なる隆起を続けていた。

苹沢川貝化石㬝および銅谷原層の両形成期には，本地 域における造瑇運動の性格が、すっかり一变した。前形 成期までの奥武士線の撓曲運動にかわって，花輪山向斜 軸の形成にともなら沈降運動が, 緩かに進行していった。

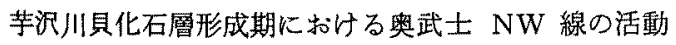
は、かずかに地域南部の厇瀬川附近に，傾動沈降の名残 りをとどめるだけで，ほかに目立った運動は，ほとんど みられない。後背地の白沢層分布地域の, 全面的な隆起 が始まり，その隆起範囲も奥武線を越えて，ともすれば， 東側の仙台層群堆積盆地にまで，抁大寸る傾向にあった。 一方東南側の三滝玄武岩搆成山地も隆起した。すなわち， 本山地周辺に分布与る，芋沢川貝化石盧中に介在寸る砂
岩は，三滰玄武岩の反映である。この上5に，東西雨 側の山地が隆起した結果，その中間に摤まれた堆積盆 には、相対的に下向きの沈降しょ5とする力が働い た。このような下向きの力とそれまで盈内に堆積した地 周の重みとが荷重となり，基盤中に潜在する NW および $\mathrm{NE}$ 方向断裂を刺载することになった。かくして，堆 䅡盈中央部に存在する沈降部が形成されたものであ。 $\tau$, 次の銅谷原層形成期に出現する, 花輸山向斜軸形成 の前触れを示寸徵候とみるこ上が出来る。

最後の銅谷原層形成期になる上，芋沢川貝化石風形成 期から継続した，地域中央部の潜在断裂は益々不安定と なって，ゆるやが沈降してゆき，花輪山向斜軸が形成 された。本軸は，前述したように，構造軸であり，また 軸部が地層中で最大層厚を示すことから，沈降軸をなす ことは明らかである。

\section{3. 造構運動の意㼁}

いままで，奥武士線および输山向斜博の性格，その 挙動およびこれら両線の活動と仙台㬝群の堆嫧との関連 性について, 解析してきた。次に本節では, これら両軸 の活動を主体とした，本地域の造構運動の特質を，主と して造構史的な観点から考察することにする。

奥武士 NW 線の撓曲運動は，中新世に活没活慟し たいわゆる「グリーンタフ変動」が、鮮新世に引継れ た一連の造構運動とみなされる。例えば，本地域の西側 隣接地域を占める白沢層中には，2回にわたる陥没性湖 盆の生成が認められ，これは中部中新世から活動してき た、NW〜SE 構造方向の運動に起因する（仙台団研 1966)。奥武士 NW 線の運動は, これら中新世の運 動の継続之考えられ，奥武士 NW 線の撓曲連動に上 る仙台層群堆積盈地の分化拉上び発展は，白沢層中の陥 没性湖登の生成に対応する運動現象である。このよらな 奥武士 NW 線の運動は，中新世において活発に活動し た、いわゆる「グリーンタフ变動」の造構パターンであ り，東北日本に抢忖るグリーンタフ变動末期の隆起軸な いし火山帯は，すべて NW〜SE 万向を示すといら生 出，大沼 (1960) らの指摘之符合する。次化奥武士 NW 線は，鮮新世の龟岡層，竜ノ口層形成期をとおして，差 別的界降運動を行ない，次いで北山㬝形成期には，それ までの隆起の中心が，反転して沈降の中心となるよらな， 激烈な陌没的傾向沈降に転し，最後に広瀬川凝灰岩形成 期における凝灰岩 (酸性火山堆積物) の惯出で，略その活 動を終っている。こういら奥武士 NW 線の運動のパタ ーンは、グリーンタフ変動の造構パターン，すなわら地

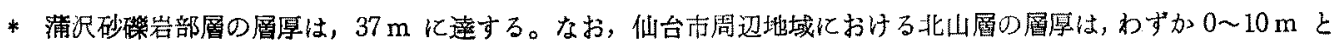
薄層である。(Hanzawa, S. and Others, 1953) 
下深部に拈ける物理学的䆖化一深部裂かの発生と岩装活 動にまつわる物理化学的過程が，地皆表㬝部人正樎力之

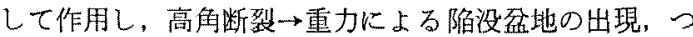
いでマグマ上年 （藤田 1969）と全く同じである。

この上5に，奥武士 NW 線の掏曲運動の運動方向和 よび運動のパターンが、グリーンタフ变動の造構運動パ ターンと一致することから，奥武士 NW 線の 運動は, 鮮新世におけるグリーンタフ夜動造構運動の延長とみな すことがでさる。換言すれば，少くとも本地域に拈いて は，鮮新世までグリーンタフ变動の造構運動が，引綕い て行なわれたことを示している。

一方，花輸山向斜軸の沈降運動は，グリーンタフ変動造 楧運動パターンとは相異なる，鮮新世後半における別タ イプの造構運動パターンと考えられる。大胆に推論を試 みれば, 花輸山向斜軸の沈降運動は，第四紀における，い わゆる新造構運動（Neo-Tectonics），の鮮新世に拈ける 先殹的な運動パターンを示唆するものかも知れない。

最後に，本地域と東南側の瞵接地域仙台市附近におけ る仙台層群上部盗の層序（本地域における芼沢川貝化石 層と銅谷原層，仙台市附近に求计る八木山層と大年 寺 蓸)が，逆になっていることについては，既に指摘したと おりりである。この原因については，本地域と仙台市附近 の堆積盈とは，それぞれ分離した独立堆積盈をなし（生 出 1955)，各堆積盆に働いた造構運動のパターンが相買 なっていた。したがって，洅堆積盈内に拈ける沈降度 が，それぞれ違っていたためと考えられる。との際本地 域に働いた造構運動は，花輪山向斜軸の沈降運動である ことは，既述したと抢りである。

\section{IV. まとめ}

今まで，浦沢イルメナイト砂鉣床堆積の背景をなした 本地域の造構運動一すなわち，奥武士線の蒸曲運動を 中心として，考察を進めてきた。これらの要点を一括す ると, 次の如くなる。

1. 蒲沢鉱床は，化石イルメナイト砂鉱床であり，第 三紀鮮新統の蒲沢砂䃏岩部㐿中に狭在する。砂鉣休の形 成は，奥武士 NW 線の造構運動に規定されている。

2. 奥武士線は，「松島一本荘带」の構造を反映した， 直角に交わる NW と NE との二軸（線）からなる。 これら両線のらち，活動の主役を演したるのは NW 線 であり，差別的界降性の莘曲運動を行って，鮮新世堆積 盆地の分化，発展お゙よび仙台層群の堆積を規定した。

3. 北山周形成期において，奥武士 NW 線の活動誌， $\mathrm{NW}$ と $\mathrm{NE}$ 両線の交又する，蒲沢鉱山附近に集中し，

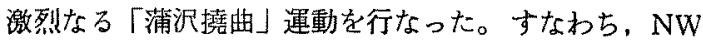

線の西南側が激しく隆起し，北東側が，陥没性の傾動沈 降を行なった。

4. かくして, 後背地の激しい隆起によつて生じた, 侵蝕産物である砕屑物が，傾動沈降により生じた前縁水 盈に流入し，溥沢砂碎岩部層が堆積しだ。本部凰は，三 角洲堆積物であって，佳 $2 \mathrm{~km}$ の円形をなす。また，岩 買が極めて粗らく，愿厚が異常に厚いことは，特殊堆積 物であることを物語っている。

5. 奥武士 NW 線の活動は，広瀬川凝灰岩形成期を bって，略終了しだ。次の芋沢川貝化石周形成期加銅 谷原層形成期には，替って花輪山向斜軸の沈降運動に終 始している。

6. 奥武士 NW 線の活動は，中新世における東北日 本の「グリーンタフ変動」造搆運動の継続とみることが でさる。すなわる，高角断裂，重力に上る陥没性盆地の 出現 $\rightarrow$ マグ、上昇 $\rightarrow$ 火山活動といらグリーンタフ变動の 典型的な造構パターンを示している。

7. 花輪山向斜軸の沈降運動は，グリーンタフ変動と は相暴なる，別タイプの造構暈動パターンとみられる。 本運動は，第四紀における新造構運動 (Neo-Tectonics) の，鮮新世における前駆的兆候を示唆するものか子知れ ない。

8. 最後に，本地域と仙台市附近における仙台層群上 部層の層序とが、逆になっていることは興味深い（本地 域の芋沢川貝化石層と銅谷原層，仙台市附近の八木山層 と大年寺層)。この事実は，兩地域の堆積盈地に働いた 造構運動パターンの相違による，沈降度の差異に起因す るもではないだろらか。

\section{引用文献}

ベロウソフ，V.V.（1954），構造地質学（地学団体研 究会部，1958），築地書館

藤田 至則 (1969)，グリーンタフ変動と島弧「グリー ンタフに関する諸問題」，地質学会訪墖会資料，2330 .

藤田至則・小林 膂・青木值昭 $(1960)$ ，東北表日本中 央部の後期中新世における 堆穦盆地分化に関する 諸問題，新生代の研究，31，760-768.

Hanzawa, S., Hatai, K., Iwai, J., Kitamura, N and Shibata, T. (1953), The geology of Sendai and its environs, Sci. Rep. Tohoku Univ., 2nd Ser., 25, 1-50.

井尼 正二 (1950)，地質学における化石床の意義と洒 值について (演旨)，地幊雑，197，648-649.

井尻 正二 (1950)，爑積学の根本問題，科学，20,298362.

生出 麇司 (1955)，「銁取一典武士線」の意義につい $\tau$ ，地球科学，25，12-20

生出 䵇司·大沼 晃助 (1960)，東北地方を中心とし 
た「グリーンタフ時代の火成活動，地球科学，5051, 36-55.

Pettijhon, F.J. (1962), Palaeocurrents and palaeogeography, Bull. Amer. Assoc. Petrol. Geol. 46. $1468-1490$.

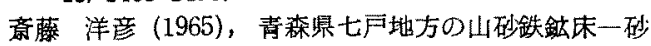

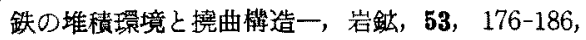

234-240

仙台団砛グルーブ (1966)，東北地万における後期中新 世の火山精造性泎没一仙台西方の 白沃層群 $の$ 地質

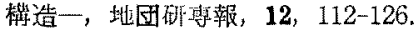

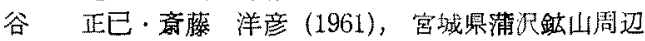
地域の含チタン砂鉄鉱床，地調月報，12，207-220. 